\title{
Barriers of utilisation of dental services among children and adolescent: A systematic review
}

\author{
Avlien Farlina*, Diah Ayu Maharani** \\ *Magister Program of Community Dentistry, Faculty of Dentistry, University of Indonesia \\ ${ }^{* *}$ Department of Preventive and Public Health Dentistry, Faculty of Dentistry, University of \\ Indonesia
}

\begin{abstract}
Introduction: Underutilisation of dental services among children and adolescent is a worldwide problem that increases caries prevalence. Younger children are less likely to receive dental care and, thus, experience oral diseases more often. This systematic review was aimed to explore the barriers of utilisation of dental services among children and adolescent. Methods: The literature search was conducted in the electronic database of Pubmed ${ }^{\odot} /$ Medline $^{\odot}$. The literature exclusion criteria were adults and qualitative study. Keywords were verified in MeSH. Boolean "AND" and "NOT" was used to specify the search. Twenty-four literature were filtered from Pubmed ${ }^{\circ}$, and twenty-three literature fit the inclusion criteria. Result: The result revealed that low-income families, minority ethnic, and disability condition have lower dental care utilisation. Conclusion: The identified potential determinants of oral health and dental care utilisation among children and adolescent are economic barriers, uninsurance, and availability of dental service providers.
\end{abstract}

Keywords: Dental care, dental services, utilisation, barrier, children, adolescent

P-ISSN 1979-0201, e-ISSN 2549-6212 Available from:http://jurnal.unpad.ac.id/pjd/article/view/15001

DOI: https://doi.org/10.24198/pjd.vol30no3.15001

Submission: Dec 21, 2017; Accepted: Nov 6, 2018; Publishing online: Nov 30,2018

\section{INTRODUCTION}

The World Health Organization Commission on Social Determinants of Health issued a report which challenged conventional public health thinking on several fronts. ${ }^{1}$ The report 'Closing the gap within a generation-health equity through action on the social determinants of health' responded to a situation in which the differences, within and between countries, in income levels, opportunities, health status, life expectancy, and access to care are higher than at any time in recent history. The Commission found abundant evidence that the valid upstream drivers of health inequities reside in the social, economic and political environments. ${ }^{1}$ Goal number three of the Sustainable Development Goals is to ensure healthy lives and promoting the well-being of all ages which is essential for sustainable development. Among all of these goals includes: achieving universal health coverage, improving access to quality essential health care services and

Corresponding author: Avlien Farlina, Magister Program of Community Dentistry, Faculty of Dentistry, University of Indonesia; M: +62-853-3991-1123; email: avlien.f@gmail.com. 
access to safe, effective, quality and affordable essential medicines and vaccines for all. ${ }^{2}$

Research on children aged 5-1 years in the US showed that only $53.6 \%$ of children who receive preventive dental treatment which is low compared to $94.7 \%$ of children receive medical prevention. ${ }^{3}$ Not many trends changes in racial/ ethnic disparities in medical and oral health access to care, and use of services in US children between 2003-2007. ${ }^{4}$ There were very few research on dental care utilisation in children in the Asia region, especially in Southeast Asia. The majority of the research we found is about dental care utilisation in adults. Research status of oral health in children in Vietnam shows that primary caries experience was associated with fluoride level in drinking water, age, gender, residential status, and geographical location. Permanent caries was also associated with dental visiting and parental education. ${ }^{5}$ This is important for us to study obstacles dental care utilisation in children, to get input to improve dental care utilisation in children in our country. Therefore, there is a need to review comprehensively barriers to the utility of health services, including dental services to assist in the identification of the problem. This review was aimed to explore the barriers to utilisation of dental services among children and adolescent.

\section{METHODS}

This review is seeking to answer the question "What are the barriers to dental services utilisation among children and adolescents?". MeSH was used to obtain appropriate terms for the keywords. Furthermore, after key search terms were identified, boolean search string was developed. The final combination of keywords and boolean were "dental care AND utilisation AND barriers AND child NOT qualitative research NOT adult". Pub Med was the database used in this review.

Inclusion and exclusion criteria were developed and are outlined in Table 1.

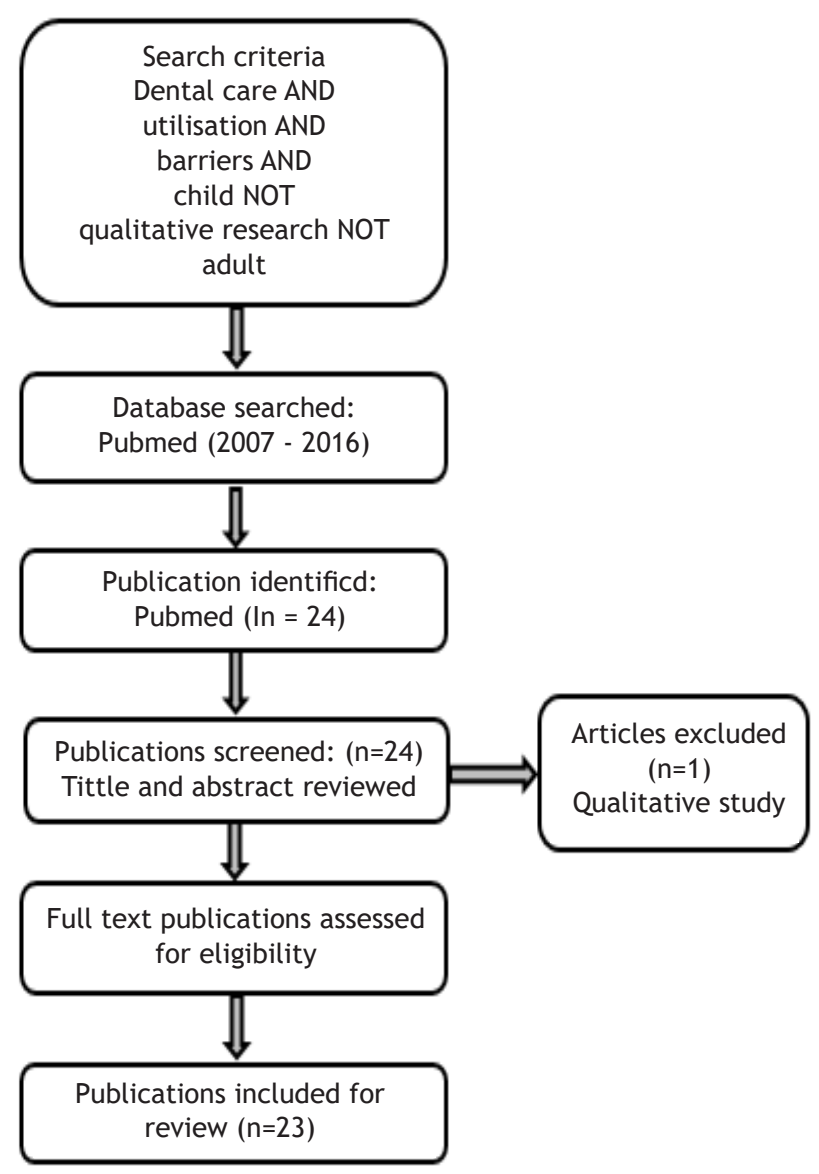

Figure 1. Flowchart of literature search and selection 
Table 1. Inclusion and exclusion criteria

\begin{tabular}{lll}
\hline \multicolumn{1}{c}{ Criteria } & \multicolumn{1}{c}{ Inclusion } & \multicolumn{1}{c}{ Exclusion } \\
\hline $\begin{array}{l}\text { Period } \\
\text { Language }\end{array}$ & From September 2007 - September 2016 & Any study outside the dates \\
Type of article & English & Non-English \\
& Original article & $\begin{array}{l}\text { Any publications that were not original } \\
\text { research, and qualitative research }\end{array}$ \\
Study Focus & Barriers to utilisation dental services among \\
children and adolescent in any condition & Adult sample \\
Geographical area of interest & $\begin{array}{l}\text { All International studies including those with } \\
\text { specific cultural groups }\end{array}$ & Nil \\
& & \\
\hline
\end{tabular}

\section{RESULT}

Our literature search identified 24 publications, and we screened these publications according to our inclusion and exclusion criteria (Figure 1). Finally, only 23 publications fit the inclusion criteria, seven publications discussed barriers to receiving dental services among low-income and homeless children, five publications discussed barriers among children with special needs, four publications discussed barriers among immigrant and minority, two publications discussed barriers among children at military area, one publication discussed barriers to receiving preventive dental services, one publication discussed the utilisation of orthodontic services, and one publication discussed a programme to overcome economic barriers.

Most of these studies were conducted in the United States, while others in Canada, UK, Spain, and India. Seventeen studies using the cross-sectional method, two community trial, two cohort study and two literature review article. Research subjects are the parents, caregivers, and children in the age range $0-19$ years using a questionnaire and secondary data analysis. Table 2 describes the studies related to this review.

Disparities in the use of dental care have been widely reported in dentistry literature. Younger children and elders, recent immigrants, poor and near-poor people and racial and ethnic minorities are less likely to receive dental care and, thus, experience dental diseases more often. A survey was administered to Spanish parents/ guardians, who were immigrants, of the patient who received preventive dental services in Arizona, indicate that the cost is more important than both convenience of appointment time and distance travelled. ${ }^{6}$ In larger scale study by the United States nationally panel survey data analysis, suggest that language barriers have a lower impact on dental care utilisation compared to parental education. ${ }^{7}$

A study in Madrid, Spain, found children of immigrant and low educations parents seldom use dental health services and have a higher risk of suffering from dental caries. ${ }^{8}$ Study of racial/ ethnic found disparities in medical and oral health status among 5 ethnics US children: Latino, African-American, Asian/Pacific Islander, Native American and multiracial. Disparities for Latinos are uninsurance, problems getting speciality care, suboptimal health status and teeth condition. Among African Americans, asthma, behavior problems, skin allergies, speech problems, and unmet prescription needs; for Native Americans, hearing or vision problems, no usual source of care, emergency department visits, and unmet medical and dental needs; and for Asians or Pacific Islanders, problems getting specialty care and not seeing a doctor in the past year while Multiracial children also experienced many disparities. ${ }^{9}$

At low-income families population, a study in Alberta, Canada, underutilization dental care caused by no perceived need $(50.7 \%)$, followed by perceived insufficient coverage (38.6\%). ${ }^{10}$ The significant barrier US low-income parents face in obtaining needed dental care for their children is a lack of financial resource. Other barriers include low numbers of dentists accepting Medicaid patients, long waiting periods for appointments, extensive travel time to appointments in rural areas, and lack of awareness about dental care needs. ${ }^{11}$

A study in U.S patients Medicaid members found all parents were aware of the Medicaid 
Table 2. Selected publication related to barriers of dental utilisation for children and adolescent

\begin{tabular}{|c|c|c|c|c|c|c|c|c|c|}
\hline No & Authors & Year & Title & Journal & Aim & Observations & $\mathrm{N}$ & Type of study & Outcome and Conclusion \\
\hline 1 & $\begin{array}{l}\text { Crall JJ, Illum } \\
\text { J, Martinez A, } \\
\text { Pourat N. }\end{array}$ & 2016 & $\begin{array}{l}\text { An Innovative Project } \\
\text { Breaks Down Barriers } \\
\text { to Oral Health Care } \\
\text { for Vulnerable Young } \\
\text { Children in Los } \\
\text { Angeles County }\end{array}$ & $\begin{array}{l}\text { UCLACenter for } \\
\text { Health Policy } \\
\text { Research. }\end{array}$ & $\begin{array}{l}\text { to improve oral health } \\
\text { care for young children } \\
\text { in } 12 \text { Federally Qualified } \\
\text { Health Center (FQHC) } \\
\text { clinic sites with co- } \\
\text { located dental and } \\
\text { primary care services } \\
\text { and it's accessibility } \\
\text { in their service areas } \\
\text { throughout Los Angeles } \\
\text { County }\end{array}$ & $\begin{array}{l}\text { children ages } \\
0-5 \text { and their } \\
\text { families }\end{array}$ & 777 & Cross-sectional & $\begin{array}{l}\text { - The project indicated twofold increases in } \\
\text { delivery of both dia } \\
\text { - gnostics and treatment visits for young } \\
\text { children, and a threefold increase in } \\
\text { preventive services for young children during } \\
\text { the program. }\end{array}$ \\
\hline 2 & $\begin{array}{l}\text { Sujlana A, } \\
\text { Baweja D, Kaur } \\
\text { A, Kaur PP. }\end{array}$ & 2016 & $\begin{array}{l}\text { Barriers of dental } \\
\text { care utilisation for } \\
\text { children living in } \\
\text { military and civilian } \\
\text { areas. }\end{array}$ & $\begin{array}{l}\text { Journal of the } \\
\text { Indian Society } \\
\text { of Pedodontic } \\
\text { and Preventive } \\
\text { Dentistry. }\end{array}$ & $\begin{array}{l}\text { to assess whether easy } \\
\text { access to dental care } \\
\text { facilities resulted in } \\
\text { improved oral health } \\
\text { and increased utilisation } \\
\text { of dental services by } \\
\text { children. }\end{array}$ & $\begin{array}{l}\text { children aged } 5 \\
\text { years from the } \\
\text { military and } \\
\text { civilian areas }\end{array}$ & 400 & Cross-sectional & $\begin{array}{l}\text { - The percentage prevalence of children } \\
\text { affected by dental caries was observed to be } \\
\text { statistically higher in the civilian sector. } \\
\text { - Covariates significantly associated with } \\
\text { increased child's dental attendance were } \\
\text { identified as: High level of the mother's } \\
\text { education, regularity of dental visits by } \\
\text { the parents, the child's increased brushing } \\
\text { frequency, and past caries experience. } \\
\text { - Dental care utilisation is not solely access- } \\
\text { related, and other barriers need to be } \\
\text { investigated. }\end{array}$ \\
\hline 3 & $\begin{array}{l}\text { Chi DL, Momany } \\
\text { ET, Mancl LA, } \\
\text { Lindgren SD, } \\
\text { Zinner SH, } \\
\text { Steinman KJ. }\end{array}$ & 2016 & $\begin{array}{l}\text { Dental Homes } \\
\text { for Children } \\
\text { With Autism: A } \\
\text { Longitudinal Analysis } \\
\text { of lowa Medicaid's } \\
\text { I-Smile Program }\end{array}$ & $\begin{array}{l}\text { A m e ric a n } \\
\text { Journal of } \\
\text { Preventive } \\
\text { Medicine }\end{array}$ & $\begin{array}{l}\text { To compared dental } \\
\text { home and preventive } \\
\text { dental utilisation rates } \\
\text { for Medicaid-enrolled } \\
\text { children by ASD status } \\
\text { and within three periods } \\
\text { (pre-implementation, } \\
\text { initial implementation, } \\
\text { maturation) and } \\
\text { determined I-Smile's } \\
\text { longitudinal influence on } \\
\text { ASD-related dental use } \\
\text { disparities. }\end{array}$ & $\begin{array}{lr}\text { children } & \text { aged } \\
3-17 & \text { years } \\
\text { identified } & \text { each } \\
\text { child's } & \text { ASD } \\
\text { status } & \end{array}$ & 30.059 & Cohort study & $\begin{array}{l}\text { - There were no significant differences in } \\
\text { dental home rates by ASD status during pre- } \\
\text { implementation, initial implementation, or } \\
\text { maturation. } \\
\text { - There were no significant differences } \\
\text { in preventive dental utilisation by ASD } \\
\text { status during pre-implementation or initial } \\
\text { implementation, but children with ASD were } \\
\text { significantly less likely to utilise preventive } \\
\text { care during maturation Longitudinal trends } \\
\text { in dental home, and preventive dental } \\
\text { utilisation rates were not significant }\end{array}$ \\
\hline
\end{tabular}




\begin{tabular}{|c|c|c|c|c|c|c|c|c|c|}
\hline 4 & $\begin{array}{l}\text { Janet U. } \\
\text { Schneiderman, } \\
\text { Susan Kools, } \\
\text { Sonya Negriff, } \\
\text { Sharon Smith, } \\
\text { and Penelope } \\
\text { K. Trickett }\end{array}$ & 2015 & $\begin{array}{l}\text { Differences in } \\
\text { Caregiver-Reported } \\
\text { Health Problems } \\
\text { and Health Care } \\
\text { Use in Maltreated } \\
\text { Adolescents and a } \\
\text { Comparison Group } \\
\text { from the Same Urban } \\
\text { Environment }\end{array}$ & $\begin{array}{l}\text { Research in } \\
\text { Nursing and } \\
\text { Health }\end{array}$ & $\begin{array}{l}\text { To compare health } \\
\text { status and health care } \\
\text { use of maltreated youth } \\
\text { who had an open case } \\
\text { with child protective } \\
\text { services to comparison } \\
\text { youth living in the same } \\
\text { community }\end{array}$ & $\begin{array}{l}\text { se condary } \\
\text { analysis of } \\
\text { care give } r \\
\text { reports for } \\
\text { mistreated } \\
\text { and comparison } \\
\text { adolescents } \\
\text { age } 10-15 \text { years }\end{array}$ & 349 & Cross-sectional & $\begin{array}{l}\text { - More mental health problems and } \\
\text { psychotropic medication use in mistreated } \\
\text { youth than in the comparison youth, } \\
\text { suggesting that mistreated youths higher } \\
\text { rates of mental health problems could } \\
\text { not be attributed to the disadvantaged } \\
\text { environment. } \\
\text { - No differences in health insurance coverage, } \\
\text { maltreated youth received preventive } \\
\text { medical care more often than comparison } \\
\text { youth. For all youth, they are having } \\
\text { Medicaid improved their odds of receiving } \\
\text { preventive health and dental care. } \\
\text { - Acceptance of Medicaid by neighbourhood- } \\
\text { based and/or school-based services in low- } \\
\text { income communities may reduce barriers to } \\
\text { preventive care. }\end{array}$ \\
\hline 5 & $\begin{array}{l}\text { Amin MS, Perez } \\
\text { A, Nyachhyon P }\end{array}$ & 2014 & $\begin{array}{l}\text { Barriers to utilisation } \\
\text { of dental services for } \\
\text { children among low- } \\
\text { income families in } \\
\text { Alberta }\end{array}$ & $\begin{array}{l}\text { Journal of } \\
\text { C a n a di a n } \\
\text { D e n t a l } \\
\text { Association. }\end{array}$ & $\begin{array}{l}\text { To explore reasons for } \\
\text { the underuse of dental } \\
\text { services covered by a } \\
\text { government - funded } \\
\text { program in Alberta. }\end{array}$ & $\begin{array}{l}\text { Children age } \\
1-19 \text { years }\end{array}$ & 1303 & Cross-sectional & $\begin{array}{l}\text { - Low-income families underuse available } \\
\text { dental benefits for children. } \\
\text { - The perceived need seems to be the primary } \\
\text { determinant of use. } \\
\text { - Parental awareness about the coverage does } \\
\text { not seem to promote the use of preventive } \\
\text { measures for young children }\end{array}$ \\
\hline 6 & $\begin{array}{l}\text { Gross-Panico } \\
\text { ML, Freeman } \\
\text { WK 3rd }\end{array}$ & 2012 & $\begin{array}{lr}\text { Identifying } & \text { barriers } \\
\text { to } & \text { receiving } \\
\text { preventive dental } \\
\text { services: expanding } \\
\text { access to preventive } \\
\text { dental } r \text { hygiene } \\
\text { services } & \text { through } \\
\text { affiliated practice }\end{array}$ & $\begin{array}{l}\text { Journal of } \\
\text { Dental Hygiene }\end{array}$ & $\begin{array}{l}\text { The research questions } \\
\text { ask if affiliated practice } \\
\text { increases utilisation } \\
\text { of preventive dental } \\
\text { services by underserved } \\
\text { and what the barriers } \\
\text { to receiving preventive } \\
\text { dental services are } \\
\text { and their level of } \\
\text { importance. }\end{array}$ & $\begin{array}{l}\mathrm{p} \text { a } \mathrm{r} \text { e } \mathrm{n} \mathrm{t} \mathrm{s} \mathrm{/} \\
\text { guardians of } \\
\text { patients from } \\
0-18 \text { years of } \\
\text { age }\end{array}$ & 34 & Cross-sectional & $\begin{array}{l}\text { The cost of preventive dental services is } \\
\text { more important to this population than } \\
\text { both convenience of appointment time and } \\
\text { distance travelled. As the cost increases for } \\
\text { preventive dental services, this population } \\
\text { will utilise preventive dental services less } \\
\text { frequently. }\end{array}$ \\
\hline 7 & $\begin{array}{l}\text { Chaffin JG, } \\
\text { Moss D, Martin } \\
\text { G, Leiendecker } \\
\text { T, Mascarenhas } \\
\text { AK. }\end{array}$ & 2013 & $\begin{array}{l}\text { Children's utilisation } \\
\text { of the U.S military } \\
\text { dental insurance }\end{array}$ & $\begin{array}{l}\text { M i l i t a r y } \\
\text { Medicine. }\end{array}$ & $\begin{array}{l}\text { to determine the dental } \\
\text { utilisation of children } \\
\text { enrolled in a military } \\
\text { dental insurance } \\
\text { program and to assess } \\
\text { if utilisation differs by } \\
\text { socioeconomic status }\end{array}$ & $\begin{array}{l}\text { Claims data } \\
\text { for children } \\
\text { enrolled in the } \\
\text { Department } \\
\text { of Defense } \\
\text { TRICARE Dental } \\
\text { Program }\end{array}$ & 376.581 & Cross-sectional & $\begin{array}{l}\text { - There was a difference in dental utilisation } \\
\text { based on the military rank of the sponsor's } \\
\text { Children of officers were } 2.5 \text { times, and } \\
\text { children of warrant officers were } 1.6 \text { times } \\
\text { more likely to have a dental visit than chil- } \\
\text { dren from enlisted families. }\end{array}$ \\
\hline
\end{tabular}


- utilisation trends within the enlisted and officer categories with higher utilisation among more senior personnel.

- Socioeconomic status does play a role in dental care-seeking behaviour of military families.

\begin{tabular}{|c|c|c|c|c|c|c|c|c|c|}
\hline 8 & $\begin{array}{ll}\text { Dela Cruz } & \text { A, } \\
\text { Mueller } & \text { G, } \\
\text { Milgrom } & \text { P, } \\
\text { Coldwell SE. }\end{array}$ & 2012 & $\begin{array}{l}\text { A community-based } \\
\text { randomised trial of } \\
\text { postcard mailings } \\
\text { to increase dental } \\
\text { utilisation among } \\
\text { low-income children }\end{array}$ & $\begin{array}{l}\text { Journal of } \\
\text { D e } \mathrm{n} \text { t i s t r y } \\
\text { for Children } \\
\text { (Chicago, III). }\end{array}$ & $\begin{array}{l}\text { to measure the impact } \\
\text { of postcard mailings } \\
\text { on dental utilisation } \\
\text { through a dental society } \\
\text { program designed to } \\
\text { increase access to } \\
\text { dental care. }\end{array}$ & $\begin{array}{l}\text { children } 2- \\
4 \quad \text { year-olds } \\
\text { low-income } \\
\text { families }\end{array}$ & 5807 & $\begin{array}{l}\text { Community } \\
\text { trial, cross- } \\
\text { sectional. }\end{array}$ & $\begin{array}{l}\text { Postcard mailings did not significantly increase } \\
\text { utilisation of preventive dental services. Oth- } \\
\text { er strategies to improve utilisation of preven- } \\
\text { tive oral health measures are needed }\end{array}$ \\
\hline 9 & $\begin{array}{l}\text { McKernan SC, } \\
\text { Kuthy RA, } \\
\text { Momany ET, } \\
\text { Mc Q u is t a n } \\
\text { MR, Hanley } \\
\text { PF, Jones MP, } \\
\text { Damiano PC }\end{array}$ & 2013 & $\begin{array}{lr}\text { G e o g r a } & \text { p h i c } \\
\text { accessibility } & \text { and } \\
\text { utilisation } & \text { of } \\
\text { orthodontic } & \text { services } \\
\text { among } & \text { Medicaid } \\
\text { children } & \text { and } \\
\text { adolescents. } & \end{array}$ & $\begin{array}{l}\text { Journal of } \\
\text { Public Health } \\
\text { Dentistry }\end{array}$ & $\begin{array}{l}\text { To describe rates } \\
\text { of Medicaid-funded } \\
\text { services provided } \\
\text { by orthodontists in } \\
\text { lowa to children and } \\
\text { adolescents, identify } \\
\text { factors associated with } \\
\text { utilisation, and describe } \\
\text { geographic barriers to } \\
\text { care. }\end{array}$ & $\begin{array}{l}\text { Me dic a id - } \\
\text { e n r o I l e d } \\
\text { children and } \\
\text { a dolescents } \\
\text { who were ages } \\
6 \text { to } 18 \text { years } \\
\text { during CY } 2008 \text { - } \\
2010\end{array}$ & 116,330 & $\begin{array}{l}\text { Retrospective } \\
\text { cohort }\end{array}$ & $\begin{array}{l}\text { - Medicaid enrollees living in small towns } \\
\text { and rural areas were more likely to utilise } \\
\text { orthodontic services than those living in } \\
\text { urban areas. } \\
\text { - Children who had an oral evaluation by a } \\
\text { primary care provider in the year before } \\
\text { the study period were more likely to receive } \\
\text { orthodontic services. } \\
\text { - Service areas with lower population } \\
\text { density and greater mean travel } \\
\text { distance to participating orthodontists } \\
\text { had higher utilisation rates than } \\
\text { smaller, more densely populated areas. }\end{array}$ \\
\hline 10 & $\begin{array}{l}\text { Melbye M, } \\
\mathrm{H} \text { u e b n e } r \\
\mathrm{CE} \text { Chi DL, } \\
\text { Hinderberger } \\
\mathrm{H}, \text { Milgrom P. }\end{array}$ & 2013 & $\begin{array}{l}\text { A first look: } \\
\text { determinants of } \\
\text { dental care for } \\
\text { children in foster } \\
\text { care }\end{array}$ & $\begin{array}{l}\text { Special Care in } \\
\text { Dentistry }\end{array}$ & $\begin{array}{l}\text { to identify potential } \\
\text { determinants of dental } \\
\text { care use and oral health } \\
\text { among children living in } \\
\text { foster care. }\end{array}$ & $\begin{array}{l}\text { health and } \\
\text { social services } \\
\text { professionals } \\
\text { experienced } \\
\text { with children } \\
\text { in foster care } \\
\text { and families } \\
\text { in western } \\
\text { Washington } \\
\text { State. }\end{array}$ & 14 & $\begin{array}{l}\text { Qualitative, } \\
\text { cross-sectional }\end{array}$ & $\begin{array}{l}\text { The identified potential determinants of oral } \\
\text { health and dental use among children living in } \\
\text { foster care include: } \\
\text { 1) linguistic and cultural barriers; } \\
\text { 2) lack of dentists willing to accept chil- } \\
\text { dren's Medicaid dental insurance; } \\
\text { 3) the lack of resources available to case- } \\
\text { workers (i.e., substantial caseload burden) } \\
\text { 4) the lack of federal funding for specialised } \\
\text { dental care; } \\
\text { 5) lack of systematic health record-keeping; } \\
\text { 6) child transience, leading to the lack of a } \\
\text { dental home; } \\
\text { 7) foster parents' competing needs; } \\
\text { 8) child behaviour problems } \\
\text { 9) lack of dental "buy in" from adolescents. }\end{array}$ \\
\hline
\end{tabular}




\begin{tabular}{|c|c|c|c|c|c|c|c|c|c|}
\hline 11 & $\begin{array}{l}\text { Stein LI, Polido } \\
\text { JC, Najera SO, } \\
\text { Cermak SA. }\end{array}$ & 2012 & $\begin{array}{lr}\text { Oral care } \\
\text { experiences and } \\
\text { challenges in } \\
\text { children with autism } \\
\text { spectrum disorder }\end{array}$ & $\begin{array}{l}\text { Pediat ric } \\
\text { Dentistry }\end{array}$ & $\begin{array}{l}\text { to investigate the } \\
\text { differences between } \\
\text { children with autism } \\
\text { spectrum disorders } \\
\text { (ASD) and their typically } \\
\text { developing peers in } \\
\text { relation to aspects of } \\
\text { oral care. }\end{array}$ & $\begin{array}{l}\text { parents of } \\
\text { ASD children } \\
\text { or typically } \\
\text { developing 2- } \\
\text { to } 18 \text {-year-olds }\end{array}$ & 396 & Cross-sectional & $\begin{array}{l}\text { - Significantly more parents of ASD children } \\
\text { than parents of typically developing children } \\
\text { reported difficulty across almost all oral } \\
\text { care variables explored, including oral care } \\
\text { in the home, at the dentist, and access to } \\
\text { oral care. } \\
\text { - This study indicates that children with au- } \\
\text { tism spectrum disorders experience great- } \\
\text { er difficulties and barriers in caring in both } \\
\text { home and dental office settings than their } \\
\text { typically developing peers. }\end{array}$ \\
\hline 12 & Lee JY. & 2012 & $\begin{array}{l}\text { Access to dental } \\
\text { health care for } \\
\text { children in North } \\
\text { Carolina }\end{array}$ & $\begin{array}{l}\text { North Carolina } \\
\text { Medical Journal }\end{array}$ & $\begin{array}{l}\text { To examines trends in } \\
\text { oral health care access } \\
\text { in the nation, as well } \\
\text { as potential barriers, } \\
\text { and finally, methods to } \\
\text { increase access in North } \\
\text { Carolina }\end{array}$ & $\begin{array}{l}\text { children ages } \\
0-18 \text { years }\end{array}$ & - & article & $\begin{array}{l}\text { - lower socioeconomic status, minority race } \\
\text { has also consistently been identified as an } \\
\text { independent risk factor for children to not } \\
\text { visit the dentist } \\
\text { - Other barriers include small numbers of } \\
\text { dentists accepting Medicaid patients, long } \\
\text { waiting periods for appointments, extensive } \\
\text { travel time to appointments in rural areas, } \\
\text { and lack of awareness about dental care } \\
\text { needs }\end{array}$ \\
\hline 13 & Nash DA & 2009 & $\begin{array}{l}\text { Improving access } \\
\text { to oral health care } \\
\text { for children by } \\
\text { expanding the dental } \\
\text { workforce to include } \\
\text { dental therapists. }\end{array}$ & $\begin{array}{l}\text { Dental Clinic of } \\
\text { North America. }\end{array}$ & $\begin{array}{l}\text { Identifies barriers } \\
\text { access to care for } \\
\text { children, describe the } \\
\text { use of dental therapists } \\
\text { and suggest a potential } \\
\text { economic advantage of } \\
\text { using a dental therapist }\end{array}$ & - & - & article & $\begin{array}{l}\text { The basic care, primary preventive and re- } \\
\text { storative care for children provided by dental } \\
\text { therapists to be equivalent in quality to the } \\
\text { dentists and more economical. }\end{array}$ \\
\hline 14 & $\begin{array}{l}\text { T a } p \text { i a } s \text { - } \\
\text { Ledesma MA, } \\
\text { Garrido PC, } \\
\text { Y Peña ME, } \\
\text { He r n á n e z- } \\
\text { Barrera V, } \\
\text { de Miguel } \\
\text { AG, Jiménez- } \\
\text { Garcia R. }\end{array}$ & 2011 & $\begin{array}{l}\text { Use of dental care } \\
\text { and prevalence } \\
\text { of caries among } \\
\text { immigrant and } \\
\text { Spanis h- b or n } \\
\text { children }\end{array}$ & $\begin{array}{l}\text { Journal of } \\
\text { De n t is t r y } \\
\text { for Children } \\
\text { (Chicago, III) }\end{array}$ & $\begin{array}{l}\text { To describe the use of } \\
\text { dental services and the } \\
\text { prevalence of dental } \\
\text { caries in children living } \\
\text { in Madrid, Spain. }\end{array}$ & $\begin{array}{l}\text { 3- to 6-year- } \\
\text { old immigrants } \\
\text { children and } \\
\text { parents }\end{array}$ & 960 & $\begin{array}{l}\text { Descriptive, } \\
\text { cross-sectional }\end{array}$ & $\begin{array}{l}\text { - Over the last year, approximately } 59 \% \text { of the } \\
\text { children had received dental care and } 28 \% \\
\text { suffered from caries. } \\
\text { - Being an immigrant and from a lower edu- } \\
\text { cation level typically results in less frequent } \\
\text { use of dental health services, and children } \\
\text { of immigrants have a higher risk of suffering } \\
\text { from dental caries. It is essential to investi- } \\
\text { gate the reasons why and introduce strate- } \\
\text { gies to reduce barriers to dental health ac- } \\
\text { cess among immigrants. }\end{array}$ \\
\hline
\end{tabular}




\begin{tabular}{|c|c|c|c|c|c|c|c|c|c|}
\hline 15 & Decker SL. & 2011 & $\begin{array}{l}\text { Medicaid payment } \\
\text { levels to dentist and } \\
\text { access to dental care } \\
\text { among children and } \\
\text { adolescents }\end{array}$ & $\begin{array}{l}\text { JAMA. The } \\
\text { Journal of } \\
\text { A m e } r \text { i c a } n \\
m \text { e d i c a l } \\
\text { association }\end{array}$ & $\begin{array}{l}\text { To describe the } \\
\text { association between } \\
\text { state Medicaid dental } \\
\text { fees in } 2 \text { years ( } 2000 \\
\text { and 2008) and children's } \\
\text { receipt of dental care. }\end{array}$ & $\begin{array}{l}\text { children and } \\
\text { adolescents ( } \\
2-17 \text { years) in } \\
\text { the National } \\
\mathrm{H} \text { e a l } \mathrm{t} \mathrm{h} \\
\text { In te rvie w } \\
\text { Survey }\end{array}$ & 33.657 & Cross-sectional & $\begin{array}{l}\text { Higher Medicaid payment levels to dentists } \\
\text { were associated with higher rates of receipt of } \\
\text { dental care among children and adolescents. }\end{array}$ \\
\hline 16 & $\begin{array}{l}\text { B rickhouse } \\
\text { TH, Farrington } \\
\text { FH, Best AM, } \\
\text { Ellsworth CW }\end{array}$ & 2009 & $\begin{array}{l}\text { Barriers to dental } \\
\text { care for children in } \\
\text { Virginia with autism } \\
\text { spectrum disorders }\end{array}$ & $\begin{array}{l}\text { Journal of } \\
\text { D e } n \text { t is t r y } \\
\text { for Children } \\
\text { (Chicago III). }\end{array}$ & $\begin{array}{l}\text { To examine the reported } \\
\text { use of dental services } \\
\text { for families of children } \\
\text { with autistic spectrum } \\
\text { disorders and identify } \\
\text { barriers that affect their } \\
\text { access to dental care. }\end{array}$ & $\begin{array}{l}\text { caregivers of } \\
\text { at least } 1 \text { child } \\
\text { with an autism } \\
\mathrm{sp} \text { e c t r u m } \\
\text { disorder }\end{array}$ & & Cross-sectional & $\begin{array}{l}\text { Children with autism spectrum disorders who } \\
\text { display challenging behaviour are less likely to } \\
\text { have a dentist for routine care, have longer } \\
\text { intervals between dental appointments, and } \\
\text { receive care when needed. }\end{array}$ \\
\hline 17 & $\begin{array}{l}\text { Chi DL, Momany } \\
\text { ET, Kuthy RA, } \\
\text { Chalmers JM, } \\
\text { Damiano PC. }\end{array}$ & 2010 & $\begin{array}{l}\text { Preventive dental } \\
\text { utilisation for } \\
\text { Medicaid-enrolled } \\
\text { children in lowa } \\
\text { identified with an } \\
\text { intellectual and/ } \\
\text { or developmental } \\
\text { disability (IDD) }\end{array}$ & $\begin{array}{l}\text { Journal of } \\
\text { Public Health } \\
\text { Dentistry }\end{array}$ & $\begin{array}{l}\text { To compare preventive } \\
\text { dental utilisation } \\
\text { for children with } \\
\text { intellectual and/or } \\
\text { developmental disability } \\
\text { (IDD) and those without } \\
\text { IDD and to identify } \\
\text { factors associated with } \\
\text { dental utilisation }\end{array}$ & $\begin{array}{l}\text { lowa Medicaid } \\
\text { dental claims } \\
\text { for a cohort of } \\
\text { children ages } \\
3-17\end{array}$ & 107.605 & Cross-sectional & $\begin{array}{l}\text { - A significantly higher proportion of non-IDD } \\
\text { children received preventive care than those } \\
\text { identified as IDD ( } 48.6 \% \text { versus } 46.1 \%) \text {. } \\
\text { - The final model revealed no statistically sig- } \\
\text { nificant difference between the two groups. } \\
\text { Factors such as older age, not residing in a } \\
\text { dental Health Professional Shortage Area, in- } \\
\text { teraction with the medical system, and fam- } \\
\text { ily characteristics increased one's likelihood } \\
\text { of receiving preventive dental care. } \\
\text { - Clinical and policy efforts should focus on } \\
\text { ensuring that all Medicaid-enrolled children } \\
\text { receive need-appropriate levels of preven- } \\
\text { tive dental care. }\end{array}$ \\
\hline 18 & $\begin{array}{l}\text { Daly B, Newton } \\
\text { JT, Batchelor P. }\end{array}$ & 2010 & $\begin{array}{l}\text { The pattern of dental } \\
\text { services use among } \\
\text { homeless people } \\
\text { using targeted } \\
\text { services }\end{array}$ & $\begin{array}{l}\text { Journal of } \\
\text { Public Health } \\
\text { Dentistry. }\end{array}$ & $\begin{array}{l}\text { To describe the patterns } \\
\text { of dental service use } \\
\text { among homeless people } \\
\text { using a targeted dental } \\
\text { service }\end{array}$ & $\begin{array}{l}\text { h o m e l e s s } \\
\text { people using a } \\
\text { targeted dental } \\
\text { service from } \\
1992 \text { to } 2001 .\end{array}$ & 204 & Cross-sectional & $\begin{array}{l}\text { - For those presenting at their first contact, } \\
40 \% \text { expressed need of oral pain and disease/ } \\
\text { tissue damage, } 28 \% \text { about dental checking } \\
\text { and oral prophylaxis. Most homeless people } \\
\text { had a normative need for dental treatment } \\
(93 \%) \text {. } \\
\text { - The targeted service was moderately suc- } \\
\text { cessful at getting people to attend the fixed } \\
\text { site service for continuing care, with } 51 \% \text { at- } \\
\text { tending for subsequent visits. Flexible atten- } \\
\text { dance tended to result in multiple visits and } \\
\text { delayed outcomes, which themselves could } \\
\text { have acted as barriers to care. }\end{array}$ \\
\hline
\end{tabular}




\begin{tabular}{|c|c|c|c|c|c|c|c|c|c|}
\hline 19 & $\begin{array}{l}\text { Noyce } \text { M, Szabo } \\
\text { A, Pajewski } \\
\text { NM, Jackson } \\
\text { S, Bradley TG, } \\
\text { Okunseri C. }\end{array}$ & 2009 & $\begin{array}{l}\text { The primary language } \\
\text { is spoken at home } \\
\text { and children's dental } \\
\text { service utilisation in } \\
\text { the United States }\end{array}$ & $\begin{array}{l}\text { Journal of } \\
\text { Public Health } \\
\text { Dentistry. }\end{array}$ & $\begin{array}{l}\text { To examine the } \\
\text { association of primary } \\
\text { language spoken at } \\
\text { home with the receipt of } \\
\text { preventive and routine } \\
\text { dental care for children } \\
\text { in the United States. }\end{array}$ & $\begin{array}{l}\text { datar from } \\
\text { the Medical } \\
\text { Expenditure } \\
\text { Panel Survey } \\
(2002-2004) \text {, } \\
\text { Among children } \\
\text { aged } 1-18 \text { years }\end{array}$ & 21.049 & Cross-sectional & $\begin{array}{l}\text { - Parental education and having a primary } \\
\text { provider were the strongest predictors of } \\
\text { preventive and routine dental visits. } \\
\text { - Children that did not speak English at home } \\
\text { were less likely to receive preventive or rou- } \\
\text { tine dental care. } \\
\text { - After adjusting for other socio-economic } \\
\text { factors, this study suggests that language } \\
\text { barriers may not play as pronounced a role } \\
\text { in the receipt of dental care }\end{array}$ \\
\hline 20 & $\begin{array}{l}\text { G re e n b e r g } \\
\text { BJ, Kumar JV, } \\
\text { Stevenson H. }\end{array}$ & 2008 & $\begin{array}{l}\text { Dental case } \\
\mathrm{m} \text { a } \mathrm{n} \text { a g e } \mathrm{m} \text { e } \mathrm{n} t \text { : } \\
\text { increasing access to } \\
\text { oral health care for } \\
\text { families and children } \\
\text { with low incomes }\end{array}$ & $\begin{array}{l}\text { Journal of } \\
\text { A m e } r i c a n \\
D \text { e } n \text { t a l } \\
\text { Association. }\end{array}$ & $\begin{array}{l}\text { To evaluate the levels } \\
\text { of participation of } \\
\text { dentists in the DCMP in } \\
\text { Medicaid and Medicaid } \\
\text { beneficiaries' use of } \\
\text { services. }\end{array}$ & $\begin{array}{l}\text { dentists who } \\
\text { treat patients } \\
\text { with Medicaid }\end{array}$ & 63 & Cross-sectional & $\begin{array}{l}\text { Dentists accepting new Medicaid patients } \\
\text { increased from two to } 28 \text {, with } 145 \text { dental visits } \\
\text { a month provided to Medicaid beneficiaries. } \\
\text { The percentage of Medicaid beneficiaries } \\
\text { receiving dental services increased from } 9 \% \text { to } \\
41 \% \text { after the DCMP was implemented. }\end{array}$ \\
\hline 21 & $\begin{array}{l}\text { Flores G, } \\
\text { To m a n y - } \\
\text { Korman SC. }\end{array}$ & 2008 & $\begin{array}{l}\text { Racial and ethnic } \\
\text { disparities in medical } \\
\text { and dental health, } \\
\text { access to care, and } \\
\text { use of services in US } \\
\text { children }\end{array}$ & Pediatrics. & $\begin{array}{l}\text { to examine racial/ } \\
\text { ethnic disparities in } \\
\text { medical and oral health, } \\
\text { access to care, and use } \\
\text { of services in a national } \\
\text { sample. }\end{array}$ & $\begin{array}{lr}\text { parents and } \\
\text { guardians } & \text { of } \\
\text { children } 0 & -17 \\
\text { years old. } & \end{array}$ & 102,353 & Cross-sectional & $\begin{array}{l}\text { Minority children experience multiple dispari- } \\
\text { ties in medical and oral health, access to care, } \\
\text { and use of services. Certain disparities are } \\
\text { particularly marked for specific racial/ethnic } \\
\text { groups, and multiracial children experience } \\
\text { many disparities. }\end{array}$ \\
\hline 22 & $\begin{array}{l}\text { Valdes } \mathrm{XL} \text {, } \\
\text { G r e e n w e ll } \\
\text { A, Theriot J, } \\
\text { Franco S. }\end{array}$ & 2007 & $\begin{array}{l}\text { Access barriers } \\
\text { to dental care for } \\
\text { Medicaid patients }\end{array}$ & $\begin{array}{l}\text { The Journal } \\
\text { of Kentucky } \\
\text { M e d i c a l } \\
\text { Association. }\end{array}$ & $\begin{array}{l}\text { understanding the reason } \\
\text { for underutilization of } \\
\text { dental services }\end{array}$ & $\begin{array}{l}\text { Parents of } \\
\text { 4-years-old } \\
\text { children were } \\
\text { surveyed at } \\
\text { a university- } \\
\text { a f f il i a t e d } \\
\text { pediatric clinic } \\
\text { with dental } \\
\text { services on site }\end{array}$ & 77 & Cross-sectional & $\begin{array}{l}\text { Parents were aware of the availability and } \\
\text { necessity of dental care in early childhood, } \\
\text { yet few of their children received the recom- } \\
\text { mended prophylactic visits. Medical care pro- } \\
\text { viders caring for children play an important } \\
\text { role as advocates of early and regular prophy- } \\
\text { lactic dental visits. }\end{array}$ \\
\hline 23 & $\begin{array}{l}\text { Nico poulos } \\
M, \quad \text { Brennan } \\
\text { MT, Kent ML, } \\
\text { Brickhouse TH, } \\
\text { Rogers } M K, \text { Fox } \\
\text { PC, Lockhart } \\
\text { PB. }\end{array}$ & 2007 & $\begin{array}{l}\text { Oral health needs } \\
\text { and barriers to dental } \\
\text { care in hospitalised } \\
\text { children. }\end{array}$ & $\begin{array}{l}\text { Special Care in } \\
\text { Dentistry. }\end{array}$ & $\begin{array}{l}\text { to examine the oral } \\
\text { health status and } \\
\text { utilisation of dental care } \\
\text { reported by hospitalised } \\
\text { children }\end{array}$ & $\begin{array}{l}\text { Hospitalised } \\
\text { children age } \\
3-12 \text { years }\end{array}$ & 120 & Cross-sectional & $\begin{array}{l}\text { A high prevalence of unmet oral health needs } \\
\text { and soft tissue abnormalities was identified in } \\
\text { a hospitalised pediatric population, } 28 \% \text { have } \\
\text { never seen a dentist. Unmet oral health needs } \\
\text { (e.g., untreated dental caries) were noted } \\
\text { in } 42 \% \text { of children, and soft tissue (mucosal) } \\
\text { abnormalities in } 59 \% \text { of children. Children with } \\
\text { chronic medical conditions reported barriers } \\
\text { to receiving dental care more often ( } 24 \% \text { than } \\
\text { children with acute medical conditions (3.5\%) }\end{array}$ \\
\hline
\end{tabular}


eligibility for services. ${ }^{12}$ The Medicaid Early Periodic Screening, Diagnosis, and Treatment (EPSDT) in North Carolina ${ }^{13}$ and Dental Case Management Program (DCMP) ${ }^{14}$ was effective in increasing Medicaid beneficiaries use of services, increasing dentist participation in Medicaid, and increasing oral health literacy and treatment compliance among client with low incomes. Higher Medicaid payment levels to dentists were associated with higher rates of receipt of dental care among children and adolescents ${ }^{15}$ while a community-based randomised trial of postcard mailings for low-income children in the Yakima County did not significantly increase utilisation of preventive dental services. ${ }^{16}$

Study retrospective cohort to examine access to orthodontic services among Medicaidenrolled children and adolescents in the lowa Medicaid represent the rate of orthodontic utilisation was 3.1\%, Rural residency and increased travel distances do not appear to act as barriers to orthodontic care for this population. ${ }^{17}$

The identified potential determinants of oral health and dental use among children living in foster care included: (1) linguistic and cultural barriers; (2) lack of dentists willing to accept children's Medicaid dental insurance; (3) lack of resources available to caseworkers (i.e. substantial caseload burden) (4) lack of federal funding for specialized dental care; (5) lack of systematic health record-keeping; (6) child transience, leading to the lack of a dental home; (8) foster parents' competing needs; (7) child behavior problems; and (9) lack of dental 'buyin' from adolescents. ${ }^{18}$ Study on mistreated youth living in urban Los Angeles, Caregivers reported similar rates of physical health problems but more mental health problems and psychotropic medication use in mistreated youth than in the comparison youth, suggesting that maltreated youths' higher rates of mental health problems could not be attributed to the disadvantaged environment although there were no differences in health insurance coverage. ${ }^{19}$

Study at Homeless population in the UK, most homeless people had a normative need for dental treatment, but flexible attendance tended to result in multiple visits and delayed outcomes, which they could have acted as barriers to care. ${ }^{20}$
In India, the percentage of children affected by dental caries in the civilian area was found to be significantly higher than in the military sector. Factors identified to positively influence the dental attendance pattern of children were found to be a high level of the mother's education, the child's previous caries experience, regular dental check-ups by the parent, and higher frequency of tooth-brushing by the child. ${ }^{21}$ Socioeconomic status does play a role in the dental care-seeking behaviour of US military families. ${ }^{22}$

Children with autism spectrum disorder (ASD) who display challenging behaviour have barriers to care in both the home and dental office. ${ }^{23,24}$ There were no significant differences in dental home rates by ASD status during preimplementation, initial implementation, or maturation. There were no significant differences in preventive dental utilisation by ASD status during pre-implementation or initial implementation, but children with ASD were significantly less likely to utilise preventive care during maturation. ${ }^{25}$ Intellectual and developmental disability (IDD) children face additional barriers to receiving dental care and may be at higher risk for dental disease; they utilise preventive dental services at the same rate as non-IDD children. ${ }^{26}$ Children with chronic medical conditions reported barriers to receiving dental care more often (24\%) than children with acute medical conditions (3.5\%). A high prevalence of unmet oral health needs and soft tissue abnormalities was identified in a hospitalised pediatric population. ${ }^{27}$

An Innovative Project Breaks Down Barriers to Oral Health Care for Vulnerable Young Children in Los Angeles County, indicated twofold increases in delivery of both diagnostics and treatment visits for young children, and a threefold increase in preventive services for young children during the program. The project funded infrastructure and staffing, provided technical assistance to improve operations, trained clinical personnel to provide oral health care to young children, implemented a quality improvement learning collaborative, educated parents and child care providers in oral hygiene and healthy habits, and disseminated information to promote effective policies. ${ }^{27}$

The other potential strategy to improve access to care and to reduce disparities among 
America's children is developing and deploying dental therapist. The preventive care provided dental therapists has been documented to be equivalent in quality to that of the dentist and more economical. ${ }^{28}$

\section{DISCUSSION}

This review shows that barriers to utilisation of dental services are almost the same throughout the world. Studies conducted in developing and developed countries show almost the same causal factors. Research in India, Spain, Canada and the USA showed the same barriers which were parental education and low income. The low income and education level of parents makes the perceived need for dental care to be low. Only in the UK show different results where the barriers that play a role are multiple visits and delayed outcomes.

Children with ASD and IDD show different obstacles in receiving dental care, namely behavioural barriers. Whereas children with chronic disease usually have soft tissue abnormalities.

According to Andersen Framework of Health Services Utilization ${ }^{29}$, an individual's access to and use of health services is considered to be a function of three characteristics.

Predisposing factors is the first characteristic, which is the socio-cultural characteristics of people that exist before their illness. The predisposing factors consisted of social structure (education, occupation, ethnicity, social networks, social interactions, and culture), health beliefs (attitudes, values, and knowledge that people have concerning and towards the health care system), demographics (age, gender).

The second characteristic is the enabling factors, which is the logistical aspects of obtaining care. The enabling factors consisted of personal or family (the means and know how to access health services, income, health insurance, a regular source of care, travel, extent and quality of social relationships), community (available health personnel and facilities, and waiting time), possible additions (genetic factors and psychological characteristics). ${ }^{30}$

The third is the need factors, which is the most immediate cause of health service use, from functional and health problems that generate the need for health care services. Need factors comprised of perceived need, which will help to understand care-seeking and adherence to a medical regimen. While evaluated need will be more closely related to the kind and amount of treatment that will be provided after a patient has presented to a medical care provider. Further, perceived means how people view their general health and functional state, as well as how they experience symptoms of illness, pain, and worries about their health and whether or not they judge their problems to be of sufficient importance and magnitude to seek professional help. On the other hand, evaluated represents a professional judgment about people's health status and their need for medical care. ${ }^{31}$

People who under dental and health utilisation rates have a weakness in three of these characteristics. Minorities ethnic, immigrants, low education, have less predisposing factors. Groups of low-income, uninsured and away from health facilities, lack of enabling factors. Whereas the lack of perceived need weakens the need factor in seeking and utilising health and dental care facilities. Cost is the most reason why unmet dental or health services, acceptance of Medicaid by neighbourhood-based and/or school-based services in low-income communities may reduce barriers use dental care.

In Indonesia, the study used secondary data from Indonesia National Socioeconomic surveys (Susenas) for 1999-2009 suggest the use of dental care services is more dependent on the ability to pay than on the need for care. ${ }^{30}$ People who lived in rural areas, who were uninsured, had higher unmet dental care needs. The perceived demand for and utilisation of dental care among Indonesians was found to be low. ${ }^{31}$ Indonesian government had implementing universal health care coverage since January 2014 to increase the quality of and access to medicines and medical treatment, especially in primary care facilities for poorly people.

\section{CONCLUSION}

Children and adolescent of low-income families, minority ethnic, and disability condition is less of dental care utilisation. The identified potential determinants of oral health and dental use among 
children and adolescent are a financial barrier, uninsurance, and availability dental services provider.

\section{REFERENCES}

1. Commission on Social Determinants of Health. Closing the gap in a generation: health equity through action on the social determinants of health. Final report of the commission on social determinants of health. Geneva: World Health Organization; 2008.

2. Sustainable Development Goals [homepage on internet]. Geneva: United Nations. 2015. 17 Goals Transform Our World. [cited 2017 Dec]; [about 4 screens]. Available from: https:// www.un.org/sustainabledevelopment/ home/.

3. Kim J, Kaste LM. Associations of the type of childcare with reported preventive medical and dental care utilization for 1 - to 5 -year-old children in the United States. Comm Dent Oral Epidemiol 2013;41(5):432-40. DOI: 10.1111/ cdoe. 12039.

4. Flores G, Lin $\mathrm{H}$. Trends in racial/ethnic disparities in medical and oral health, access to care, and use of services in US children: has anything changed over the years? Int J Equity Health 2013;12:10. DOI:10.1186/1475-927612-10.

5. Do LG, Spencer AJ, Roberts-Thomson KF, Trinh HD, Nguyen TT. Oral Health Status of Vietnamese Children: Findings From the National Oral Health Survey of Vietnam 1999. Asia Pac J Public Health 2011;23(2):217-27. DOI: $10.1177 / 1010539509340047$.

6. Gross-Panico ML, Freeman WK 3rd. Identifying barriers to receiving preventive dental services: expanding access to preventive dental hygiene services through affiliated practice. J Dent Hyg 2012;86(4):306-14.

7. Noyce M, Szabo A, Pajewski NM, Jackson S, Bradley TG, Okunseri C. Primary language spoken at home and children's dental service utilization in the United States. J Public Health Dent. 2009;69(4):276-83. DOI: 10.1111/j.1752-7325.2009.00135.x.

8. Tapias-Ledesma MA, Garrido PC, Y Peña ME, Hernánez-Barrera V, de Miguel AG, JiménezGarcia R. Use of dental care and prevalence of caries among immigrant and Spanish-born children. J Dent Child (Chic) 2011;78(1):3642.

9. Flores G, Tomany-Korman SC. Racial and Ethnic Disparities in Medical and Dental Health, Access to Care, and Use of Services in US Children. Pediatrics. 2008;121(2): e286-98. DOI: 10.1542/peds.2007-1243.

10. Amin MS, Perez A, Nyachhyon P. Barriers to utilization of dental services for children among low-income families in Alberta. J Can Dent Assoc 2014;80:e51.

11. Valdes XL, Greenwell A, Theriot J, Franco S. Access barriers to dental care for Medicaid patients. J Ky Med Assoc 2007;105(10):491-5.

12. Lee JY. Access to dental health care for children in North Carolina. North Carolina Med J 2012;73(2):115-6.

13. Greenberg BJ, Kumar JV, Stevenson H. Dental case management: increasing access to oral health care for families and children with low incomes. J Am Dent Assoc 2008;139(8):111421. DOI: 10.14219/jada.archive.2008.0314.

14. Decker SL. Medicaid payment levels to dentists and access to dental care among children and adolescents. JAMA 2011;306(2):187-93. DOI: 10.1001/jama.2011.956.

15. Dela Cruz A, Mueller G, Milgrom P, Coldwell SE. Community-based randomized trial of postcard mailings to increase dental utilization among low-income children. J Dent Child (Chic) 2012;79(3):154-8.

16. McKernan SC, Kuthy RA, Momany ET, McQuistan MR, Hanley PF, Jones MP et al. Geographic accessibility and utilization of orthodontic services among Medicaid children and adolescents, J Public Health Dent 2013; 3(1):56-64. DOl:10.1111/jphd.12006.

17. Melbye M, Huebner CE, Chi DL, Hinderberger H, Milgrom P. A First Look: Determinants of Dental Care for Children in Foster Care. Spec Care Dentist. 2013;33(1):13-19. DOI:10.1111/ j.1754-4505.2012.00312.x.

18. Schneiderman JU, Kools S, Negriff S, Smith S, Trickett PK. Differences in Caregiver-Reported Health Problems and Health Care Use in Maltreated Adolescents and a Comparison Group from the Same Urban Environment. Res Nurs Health. 2015;38(1):60-70. DOI:10.1002/ nur.21634. 
19. Daly B, Newton JT, Batchelor P. Patterns of dental service use among homeless people using a targeted service. J Public Health Dent. 2010;70(1):45-51. DOI: 10.1111/j.17527325.2009.00142.x.

20. Sujlana A, Baweja D, Kaur A, Kaur PP. Barriers of dental care utilization for children living in military and civilian areas. J Indian Soc Pedod Prev Dent 2016;34(2):115-9. DOI: 10.4103/0970-4388.180410.

21. Chaffin JG, Moss D, Martin G, Leiendecker T, Mascarenhas AK. Children's Utilization of the U.S. Military Dental Insurance. Mil Med. 2013;178(7):816-8. DOI: 10.7205/ MILMED-D-13-00089.

22. Stein LI, Polido JC, Najera SO, Cermak SA. Oral care experiences and challenges in children with autism spectrum disorders. Pediatr Dent 2012;34(5):387-91.

23. Brickhouse TH, Farrington $\mathrm{FH}$, Best $\mathrm{AM}$, EllsworthCW. Barriers todental careforchildren in Virginia with autism spectrum disorders. J Dent Child (Chic) 2009;76(3):188-93.

24. Chi DL, Momany ET, Mancl LA, Lindgren SD, Zinner SH, Steinman KJ. Dental Homes for Children With Autism: A Longitudinal Analysis of lowa Medicaid's I-Smile Program. Am J Prev Med. 2016;50(5):609-15. DOI: 10.1016/j. amepre.2015.08.022.

25. Chi DL, Momany ET, Kuthy RA, Chalmers JM, Damiano PC. Preventive dental utilization for
Medicaid-enrolled children in lowa identified with intellectual and/or developmental disability. J Public Health Dent 2010;70(1):3544. DOI: 10.1111/j.1752-7325.2009.00141.x.

26. Nicopoulos M, Brennan MT, Kent ML, Brickhouse TH, Rogers MK, Fox PC, et al. Oral health needs and barriers to dental care in hospitalized children. Spec Care Dent 2007;27(5):206-11. DOI: 10.1111/j.1754-4505.2007.tb00348.x.

27. Crall JJ, Illum J, Martinez A, Pourat N. An Innovative Project Breaks Down Barriers to Oral Health Care for Vulnerable Young Children in Los Angeles County. Policy Brief UCLA Cent Health Policy Res 2016;(PB2016-5):1-8.

28. Nash DA. Improving access to oral health care for children by expanding the dental workforce to include dental therapists. J Dent Hyg 2009;83(1):36-44.

29. Andersen RM. Revisiting the behavioral model and access to medical care: does it matter? J Health Soc Behav 1995;36(1):1-10.

30. Maharani DA. Do the indonesians received the dental care treatment they need? A secondary data on self-perceived dental care need. ISRN Dent 2012; 2012:769809. DOI:10.5402/2012/769809.

31. Maharani DA, Rahardjo A. Is the utilization of dental care based on need or socioeconomic status? A study of dental care in Indonesia from 1999-2009. Int Dent J 2012;62(2):90-4. DOl:10.1111/j.1875-595x.2011.00095.x. 